\title{
A Preliminary Study on the Removal of Methylene Blue from Aqueous Solution using Moringa Pods as Bioadsorbent under Column Operation
}

\author{
Mirla Rodríguez ${ }^{\mathrm{a},{ }^{*}, \text { Saúl Flores }}{ }^{\mathrm{a}}$ and Alexandra Argotte $^{\mathrm{b}}$ \\ ${ }^{a}$ Ecology Center, Venezuelan Institute of Scientific Research, Venezuela \\ ${ }^{b}$ Electronic Microscopy Unit, Chemistry Center, Venezuelan Institute of Scientific Research, Venezuela
}

\begin{abstract}
Moringa pods (MP) was used as bioadsorbent to remove methylene blue (MB) from aqueous solutions under fixed-bed column operation. The bioadsorbent was analyzed by Fourier transform infrared spectroscopy (FT-IR) and scanning electron microscopy (SEM). Surface area (Brunauer-Emmet-Teller) and point of zero charge ( $\mathrm{pH}$ PzC) were determined. In this study, pH influence (2.0 to 10.0) was evaluated, keeping constant conditions of bed height $(11.0 \mathrm{~cm})$, bioadsorbent dose $(2.0 \mathrm{~g})$, dye concentration $\left(20 \mathrm{mg} \mathrm{L}^{-1}\right)$, volume $(25 \mathrm{~mL})$, contact time $(24 \mathrm{~h})$ and room temperature. The MB concentration was determined using UV-spectrophotometry at $662 \mathrm{~nm}$. The results showed that the adsorption was $\mathrm{pH}$ dependent. The highest dye removal occurs at $\mathrm{pH} 7.0(-100 \%)$. Infrared spectrum and morphological changes observed by SEM indicate the existence of bioadsorption phenomenon. An adsorption mechanism possible by intermolecular interactions was proposed. The study revealed the applicability of MP for removal of MB at low cost, efficient, eco-friendly and relatively neutral $\mathrm{pH}$.
\end{abstract}

Keywords: Agricultural waste, cationic dye, adsorption, aqueous system, fixed-bed.

\section{INTRODUCTION}

Methylene blue (MB) is a common dye mostly used by industries involve in textile, paper, rubber, plastics, leather, cosmetics, pharmaceutical and food industries. Effluents discharged from such industries contain residues of dyes. Consequently, the presence of very low concentrations in effluent is highly visible [1]. Although, methylene blue is not strongly hazardous, it can cause some harmful effects, such as heartbeat increase, vomiting, shock, cyanosis, jaundice, quadriplegia, and tissue necrosis in humans [2]. Therefore, the treatment of effluents containing such dye is of great interest due to its harmful impacts on receiving waters [2].

Several methods have been used for the removal of dyes from aqueous system, including biological, physical, chemical and biological processes. Due to structure complexity and low biodegradability, conventional biological methods are not very effective. Thus, dyes are usually treated with either by physical or chemical processes [3]. Among them, adsorption on activated carbon has been shown to be very effective for removal of dyes and other pollutants from aqueous solutions due to its large surface area, microporous structure, high adsorption capacity, and so forth. However, its commercial use is limited because of its high cost of manufacturing and problems associated

*Correspondence Address to this author at the Ecology Center, Venezuelan Institute of Scientific Research, Venezuela; Tel: +58 414 4016418;

E-mail: rodrigsmj@gmail.com with regeneration or disposal of spent carbon [4]. This has recently prompted many studies on production of low cost alternatives adsorbents. A number of agricultural waste types and byproducts of cellulosic source have been studied for their capacity to remove dyes from aqueous solutions [5]. Some lignocellulosic materials with rough surfaces, pores of various sizes, and active functional groups on their surface may have a great potential as adsorbents, and they are abundant in nature [6]. The adsorptive capability of lignocellulosic materials to environmental protection via adsorbing diverse organic and inorganic pollutants from aqueous solution to clean wastewater has been widely studied [6]. Several types of agricultural waste such as raw corn cobs [7], dragon fruit skin [8], rice husk [9], peanut shell [9] and maize tassels [10] have been used for the removal of methylene blue from aqueous solution. Moreover, adsorption studies of methylene blue by peanut husk in column modes have been reported [11]. Adsorption using column is one of the most common and efficient way for removal of pollutants from water [12].

Nowadays, large amounts of agricultural waste, such as moringa pods are produced in Venezuela. Moringa (Moringa oleifera Lam.) belong to the Moringaceae family and it originated from the India's northeast. The specie is known for its high nutritional value, and almost all parts of the plant are used as food as well as having medicinal and industrial importance [13]. Moringa seeds can be considered as a natural material which presents some important characteristics 
in relation to its application in effluent treatment. The seeds have been used for treatment of turbid water due to their flocculation properties [14]. Several studies have been carried out using moringa seeds as an adsorbent for the removal of heavy metals such as cadmium [13], nickel [14], manganese [15], copper, chromium, lead and zinc [16] and dyes [17] from aqueous solutions. There are few works on metal ions adsorption using moringa pods [18, 19]. At present, the use of moringa pods as a bioadsorbent of dyes in aqueous solution has not been reported.

The aim of this research work was to investigate the ability of Moringa pods as a bioadsorbent for removal of methylene blue from aqueous solutions. The effect of solution $\mathrm{pH}$ under fixed-bed column operation was evaluated.

\section{EXPERIMENTAL}

This study has been performed in the Laboratory of Soil Ecology, Ecology Center, Venezuelan Institute of Scientific Researches. Miranda, Venezuela.

\subsection{Preparation of Bioadsorbent and its Characterization}

Moringa oleifera pods (MP) were collected from Guárico State, Venezuela. Pods were dried in an oven at $60{ }^{\circ} \mathrm{C}$ for a $24-\mathrm{h}$ period. After drying, pods were grounded using a commercial blender (FISHER). Subsequently, the resultant powders be sieving to a particle size of $595 \mu \mathrm{m}$. Finally, were collected in a plastic bag at room temperature and used as bioadsorbent for adsorption experiments. The MP powders were characterized using several techniques.

\subsubsection{Fourier Transform Infrared Spectroscopy (FT- IR)}

Fourier transform infrared spectrophotometry (FTIR) was used to identify the different functional groups available on the bioadsorbent sites and their effect on dye adsorption. The FTIR of the adsorbent was taken before and after adsorption using FTIR spectrophotometer (Elmer Perkin Spectrum 100). The FTIR spectrum was then recorded within the wave number range $4,000-500 \mathrm{~cm}^{-1}$.

\subsubsection{Scanning Electronic Microscopy (SEM)}

Moringa pods morphology and texture before and after of the MB adsorption was evaluated by scanning electronic microscopy (SEM) Quanta $250 \mathrm{~W}$ model.

\subsubsection{Specific Surface Area (BET)}

The specific surface area was determined by nitrogen sorption at 77K (Micromeritics, ASAP 2010) using the Brunauer-Emmet-Teller (BET) method from data in $\mathrm{P} / \mathrm{Po}$ range of 0.66 to 0.2 .

\subsubsection{Point of Zero Charge ( $\mathrm{pH} P \mathrm{PZC})$}

As further characterization, the point of zero charge $\left(\mathrm{pH}_{\mathrm{PzC}}\right)$ of the moringa pods was determined according to Mimura et al. [20]. The procedure consisted of adding $50 \mathrm{mg}$ of the bioadsorbent in $50 \mathrm{ml}$ aqueous potassium chloride solution $(\mathrm{KCl})$ at 0.05 and 0.5 $\mathrm{molL}^{-1}$ with initial $\mathrm{pH}$ values ranging from 2.0 to 9.0 , which were adjusted with solutions of hydrochloric acid $(\mathrm{HCl})$ and sodium hydroxide $(\mathrm{NaOH})$ both at $0.1 \mathrm{~mol}$ $\mathrm{L}^{-1}$. After $24 \mathrm{~h}$ of stirring (200 rpm), the final $\mathrm{pH}$ values were obtained, resulting in a graph with initial $\mathrm{pH}$ depending on the final $\mathrm{pH}$, being that the $\mathrm{pH}$ range there was no change to the final $\mathrm{pH}$ corresponds to the $\mathrm{pH}_{\mathrm{PZC}}$.

\subsection{Preparation of Methylene Blue Solution}

The methylene blue trihydrate (MB, $99.5 \%$, supplied by AUT LABOR, Ind. Brasileira) was taken as the model dye in this study. The molecular weight of MB is $373.9 \mathrm{~g} \mathrm{~mol} \mathrm{~g}^{-1}$ and molecular formula $\mathrm{C}_{16} \mathrm{H}_{18} \mathrm{~N}_{3} \mathrm{SCl} .3 \mathrm{H}_{2} \mathrm{O}$. The chemical structure is presented in Figure 1. The stock dye solution was prepared by dissolving $1 \mathrm{~g}$ of $\mathrm{MB}$ in $1,000 \mathrm{~mL}$ distilled water. The $\mathrm{pH}$ of the experiment solutions was adjusted by adding either dilute $0.1 \mathrm{M} \mathrm{HCl}$ or $0.1 \mathrm{M} \mathrm{NaOH}$ solutions. The $\mathrm{pH}$ measurements were performed using an FISHER ACCUMET $\mathrm{pH}$ meter (230A model). The experimental solutions were obtained by diluting the stock dye solution with distilled water to give the appropriate concentration range of experimental solutions.

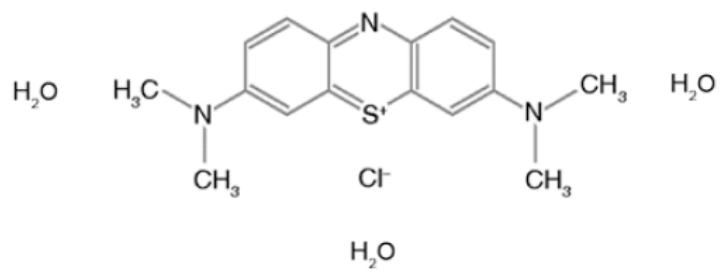

Figure 1: Chemical structure of methylene blue.

\subsection{Calibration Standard Curve of Methylene Blue}

The calibration standard curve of absorbance against methylene blue concentration was obtained by using standard MB solutions at $\mathrm{pH}$ 7. The experimental data reported in Figure 2 were fitted by a straight line with a high regression coefficient value $\left(R^{2}=0.996\right)$. 


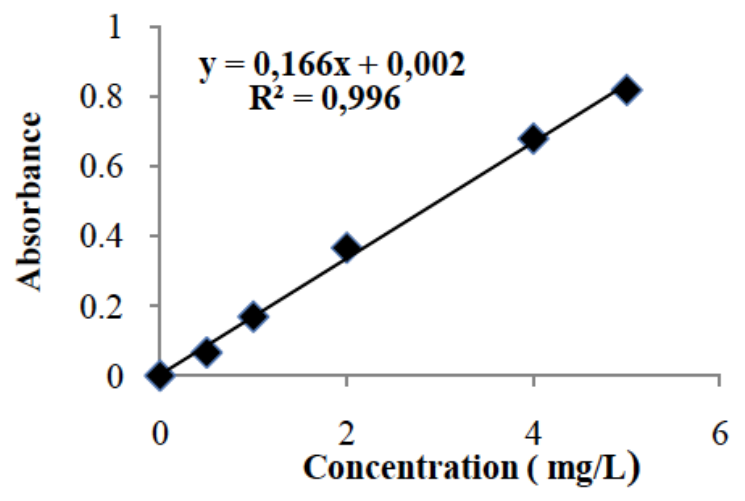

Figure 2: Calibration curve of methylene blue.

\subsection{Adsorption Studies}

In this study, the ability to capture the methylene blue dye on moringa pods in a fixed-bed column under static conditions was evaluated (as a preliminary test).

Adsorption studies were carried out in a glass column of $(25 \mathrm{~cm})$ height and $(2 \mathrm{~cm})$ inner diameter. A known quantity of the moringa pods was packed in the column to yield the desired bed height of the bioadsorbent. Subsequently, MB solution was introduced to the column through of a glass beaker. Samples were collected at $24 \mathrm{~h}$. The treatment system and process used in the study is shown in Figure 3. In this study, effect of $\mathrm{pH}(2.0,4.0,6.0,7.0,8.0$ and 10.0) of MB solution was evaluated, keeping constant conditions of bed height $(11.0 \mathrm{~cm})$, bioadsorbent dose $(2.0 \mathrm{~g})$, dye concentration (20 mg L-1), volume $(25 \mathrm{~mL})$, contact time $(24 \mathrm{~h})$ and room temperature. All samples were taken from the outlet of the column. The concentrations of methylene blue (MB) in the solutions were determined by measuring absorbance of the dye by using a UV spectrophotometer (model: Genesys 2) at a maximum wavelength $(\lambda \max =662 \mathrm{~nm})$ using the calibration curve shown in Figure 2.

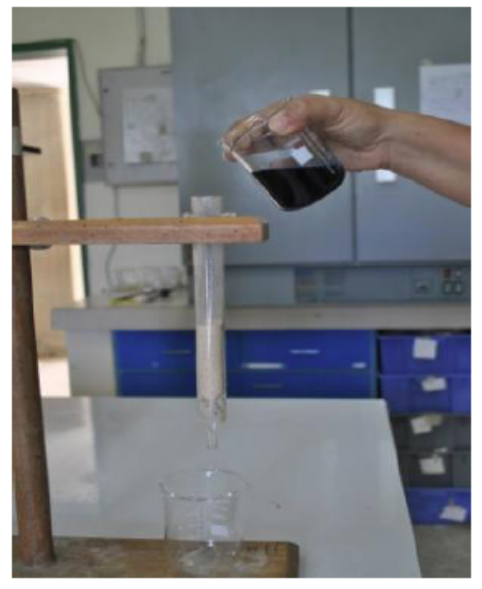

Figure 3: Column packed with MP for MB removal.
To express the \% of dye removal, the following equation was used:

$$
\% \text { dye removal }=\frac{\mathrm{Co}-\mathrm{Cf}}{\mathrm{Co}} \times 100
$$

Where, Co $\left(\mathrm{mg} \mathrm{L}^{-1}\right)$ and $\mathrm{Cf}\left(\mathrm{mg} \mathrm{L}^{-1}\right)$ represent the initial and final dye concentration respectively.

\section{RESULTS AND DISCUSSION}

\subsection{Infrared Spectrophotometry (FT-IR)}

Figure 4 shows FT-IR spectrum of moringa pods before of methylene blue adsorption. The FT-IR spectrum of MP displays a number of absorption peaks, indicating the complex nature of the biosorbent. The broad band centered at $3,413 \mathrm{~cm}^{-1}$ may be attributed to the stretching of the $\mathrm{OH}$ and $\mathrm{N}-\mathrm{H}$ groups present in proteins, fatty acids, carbohydrates (cellulose and hemicelluloses), lignin and water absorbed [21]. The peaks present at $2,919 \mathrm{~cm}^{-1} \mathrm{y}$ $2,851 \mathrm{~cm}^{-1}$, respectively, correspond to asymmetric and symmetric stretching of the $\mathrm{C}-\mathrm{H}$ bond of the $\mathrm{CH}_{2}$ group. In the region of $1,800-1,500 \mathrm{~cm}^{-1}$ a number of overlapping bands are observed and between 1,735 and $1,634 \mathrm{~cm}^{-1}$ this can be attributed to $\mathrm{C}=\mathrm{O}$ stretching. Due to the heterogeneous nature of the pods, the carbonyl group may be bonded to different neighborhoods as part of the fatty acids of the lipid portion or amides of the protein portion. The peak observed at $1,510 \mathrm{~cm}^{-1}$ may be attributed to stretching connecting $\mathrm{C}-\mathrm{N}$ and also the deformation of the $\mathrm{N}-\mathrm{H}$ bond [22] present in proteins of moringa pods. The peaks at $1,108-1039 \mathrm{~cm}^{-1}$ may be attributed to the vibrational stretching of $\mathrm{C}-\mathrm{O}$ bond of amide and carboxylic groups $(-\mathrm{COOH})$, which are characteristic bands of lignocellulosic materials. The band at 1,059 attributed to $\mathrm{C}-\mathrm{O}$ stretching also suggests the presence of lignin [13]. Similar types of FTIR spectra have been reported by few other investigators [11]. FTIR spectrum of MP after methylene blue adsorption (Figure 5) illustrates showed similar characteristics as that of moringa pods but with small variations in the intensity of the band at $3,413 \mathrm{~cm}^{-1}$. As methylene blue is a cationic dye, the $-\mathrm{OH}$ functional group on the surface of MP may increase the interaction between the adsorbent and the adsorbate, which contributes to the adsorption of methylene blue [5]. Also, can be observed a decrease of the intensity of the band at $1,634 \mathrm{~cm}^{-1}$ and a shifted slightly, due probably to the interaction between dye molecule and $-\mathrm{OH}$ and $\mathrm{COOH}$ groups present on bioadsorbent surface. When 
infrared light interacted with the adsorbent, it caused different types of vibration such as stretching, contraction and bending of its chemical bonds. As a result, the chemical functional group tends to absorb infrared radiation in a specific wavelength range. The analysis of FTIR spectrum showed the presence of ionizable groups (hydroxyl and carboxyl) able to interact with protons, metal or positive dye ions [11].

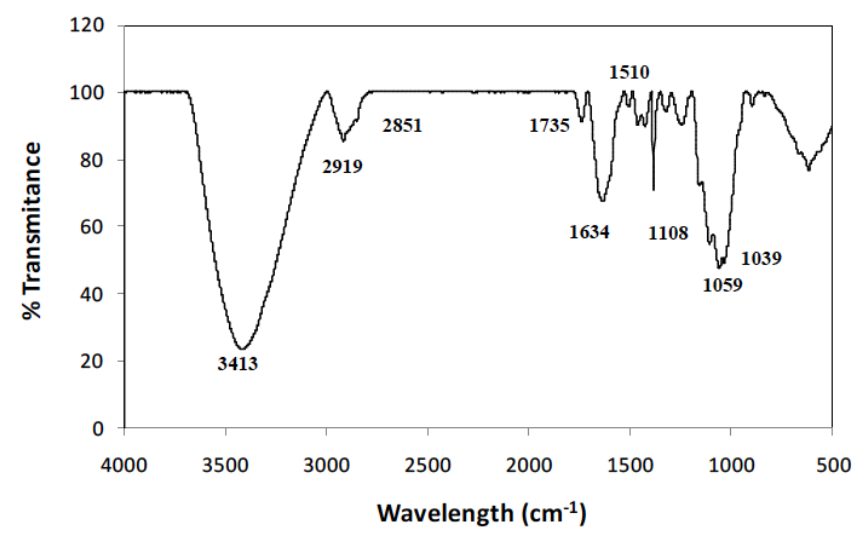

Figure 4: FT-IR spectrum of moringa pods.

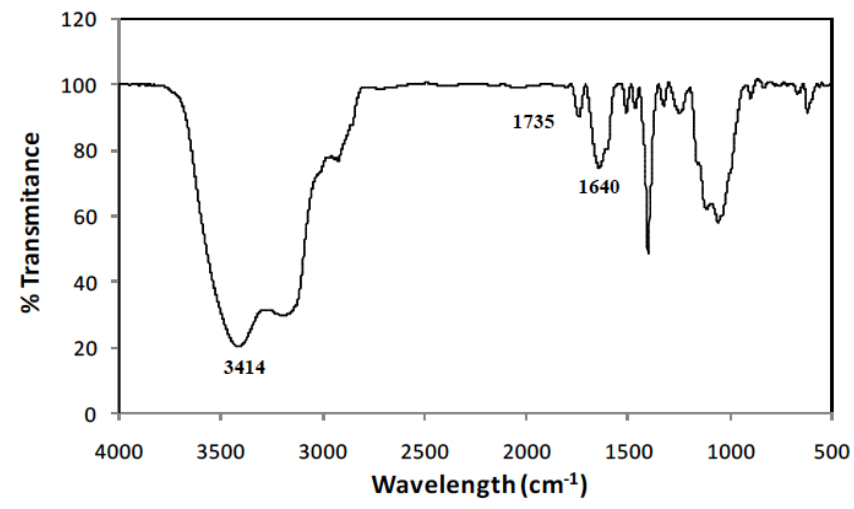

Figure 5: FTIR spectrum of MP after MB adsorption.

\subsection{Scanning Electronic Microscopy (SEM)}

Figure 6 shows SEM micrographs of MP before and after of MB adsorption. The images indicate that the material surface exhibits a relatively porous and heterogeneous structure. This feature is attributed to the fact that the whole pod comprises a wide variety of material components. The presence of fibrous aspect and some deformations on the surface of material can be observed, containing available sites, from which it is possible to infer that the bioadsorbent provides favorable conditions for the adsorption of ionic species in the interstices (Figure 6a). A magnification of the micrograph shown in the Figure $\mathbf{6 b}$ clearly reveals the presence of irregular cylindrical structures of different diameters between $19 \mu \mathrm{m}$ and $35 \mu \mathrm{m}$, which could act as active sites in the adsorption of dyes. After of adsorption process with the methylene blue, a change in the morphology of the material is observed. Figure $6 c$ illustrates the MB molecules adsorbed on adsorbent surface and therefore the morphology of the MP surface has been changed significantly. This clearly reveals that the surface of adsorbent is covered with dye molecules. Additionally, a more regular structure is also observed, which indicates that the dye was uniformly adsorbed on the surface of the bioadsorbent. Similar results have been observed by other researchers [5].
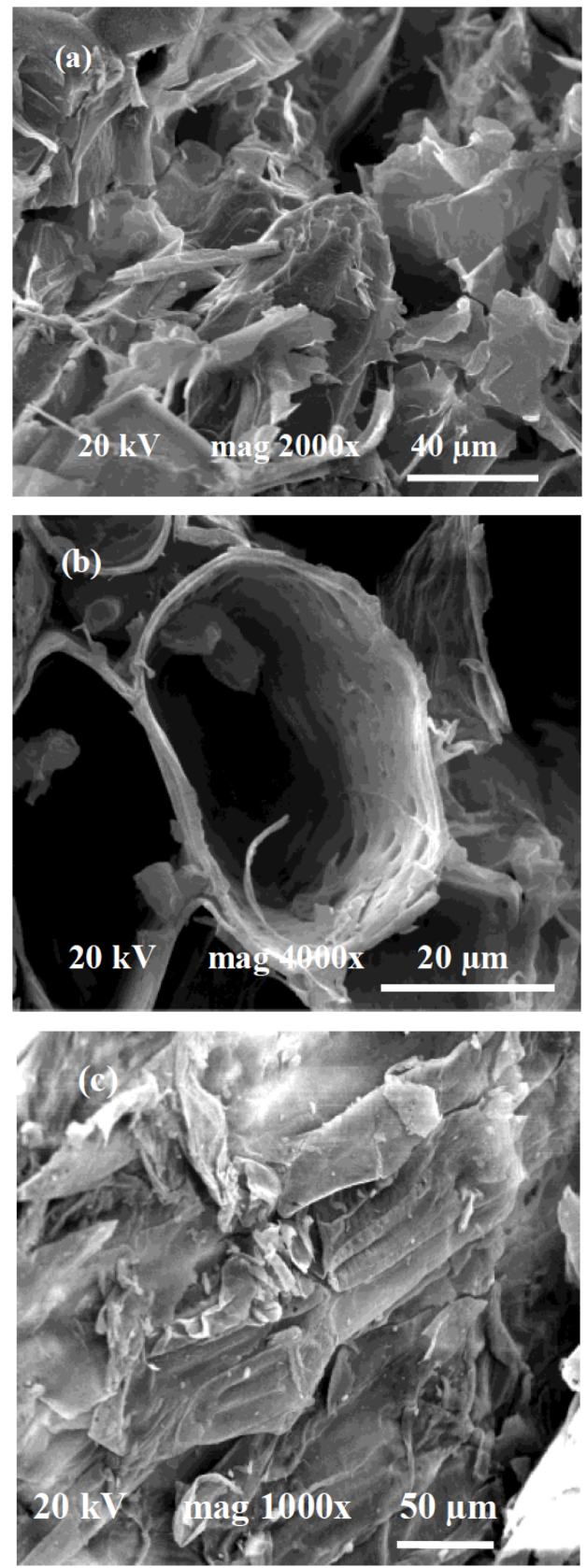

Figure 6: SEM images of MP showing: (a) a heterogeneous surface, (b) cylindrical structures and (c) after of $\mathrm{MB}$ adsorption at $\mathrm{pH} 7$. 


\subsection{Specific Surface Area (BET)}

The specific surface area (BET) of moringa pods was $6.0 \mathrm{~m}^{2} \mathrm{~g}^{-1}$. The use of adsorbent with BET surface area much lower in the removal of methylene blue from aqueous system has also been reported [4, 23-25].

\subsection{Point of Zero Charge ( $\left.\mathrm{pH}_{\mathrm{Pzc}}\right)$}

The $\mathrm{pH}$ is one of the most important parameters affecting any adsorption process. This dependence is closely related to the acid-base properties of various functional groups on the adsorbent surfaces [18]. The influence of $\mathrm{pH}$ on adsorption can be describe on the basis point zero changes $\left(\mathrm{pH}_{\mathrm{PzC}}\right)$, which is the point at which the net charge of the adsorbent is zero [2]. Depending on the $\mathrm{pH}$ of the solution, their surfaces can be positively or negatively charged. At $\mathrm{pH}$ values greater than pHpzc, the biomass surface becomes negatively charged, favoring the adsorption of cationic species. However, adsorption of anionic species will be favored at $\mathrm{pH}<\mathrm{pHpzc}$ [26]. In order to understand the mechanism involved in the adsorption process of the methylene blue on the bioadsorbent, it is necessary to determine the zero charge point $\left(\mathrm{pH}_{\mathrm{PzC}}\right)$ of moringa pods. The results obtained in $\mathrm{KCl}$ solutions indicated that the $\mathrm{pH}_{\mathrm{PzC}}$ for moringa pods is about $\mathrm{pH} 6.0$ (Figure 7 ). Thus, the adsorption of cations in case of cationic dyes is favored at $\mathrm{pH}$ values above the $\mathrm{pH}_{\mathrm{Pzc}}$. Similar results were reported for waste materials of Daucus carota [2].

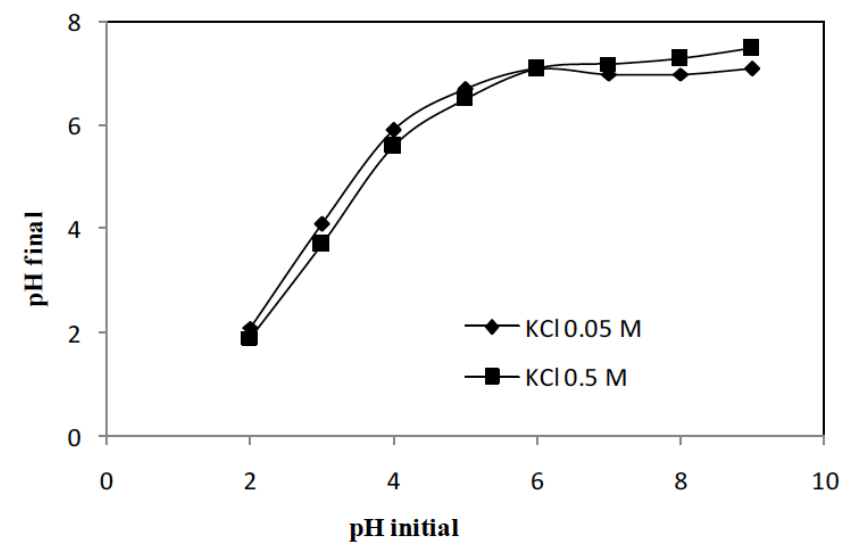

Figure 7: Point of zero charge $\mathrm{pH}_{\mathrm{PCZ}}$ of MP.

\subsection{Adsorption Studies}

Figure 8 shows the cylindrical glass column packed with moringa pods for removal of a methylene blue solution at $\mathrm{pH} 7$. The results clearly show the presence of a blue ring retained on the surface of bioadorbent corresponding to the methylene blue and a transparent filtrate was obtained. This indicates that MP particles packed in the column exhibit a remarkable ability to retain cationic dye on the surface of bioadsorbent at neutral $\mathrm{pH}$.

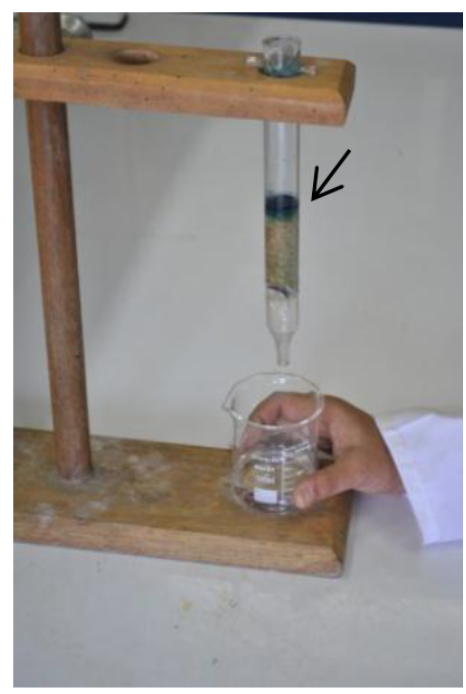

Figure 8: Methylene blue retained on MP.

\subsection{Influence of Solution $\mathrm{pH}$}

The influence of solution $\mathrm{pH}$ on methylene blue removal using moringa pods is shown in Figure 9. The effect of $\mathrm{pH}$ was examined in the range of 2.0 to 10.0 under conditions of room temperature. The removal of dye increased with the increase in $\mathrm{pH}$ of solution from 2.0 to 6.0. The highest dye removal occurs at $\mathrm{pH} 7.0$ $(100 \%)$. At $\mathrm{pH} 7$, surface of moringa pods was negatively charged to its maximum extend, confirming the results obtained in the study of $\mathrm{pH}_{\mathrm{PZC}}$. Similar results have been reported for adsorption of methylene blue on waste materials of Daucus carota [2], maize tassels [10] and pine cone [24]. However, the uptake capacity does not change significantly from $\mathrm{pH} 8.0$ to 10.0 and the removal efficiency is kept practically constant (variations lower than $2 \%$ ). A similar trend was observed for MB adsorption on papyrus plant [27]. At solution of $\mathrm{pH}<\mathrm{pH}_{\mathrm{PzC}}$, the moringa pods surface may get positively charget due to adsorption of the $\mathrm{H}^{+}$ ions and a force of repulsion occurs between the dye cation and the bioadsorbent surface. Also, $\mathrm{H}^{+}$ concentration is high at lower $\mathrm{pH}$ due to which there is a competition for vacant adsorption sites between $\mathrm{H}^{+}$ and positively charged $\mathrm{MB}$ cation. This leads to lowering of the adsorption capacity [4]. At solution of $\mathrm{pH}>\mathrm{pH}_{\mathrm{PZC}}$, the surface of moringa pods may get negatively charged due to adsorption of $\mathrm{OH}^{-}$, and the adsorption process is highly favored though electrostatic force of attraction [4]. 


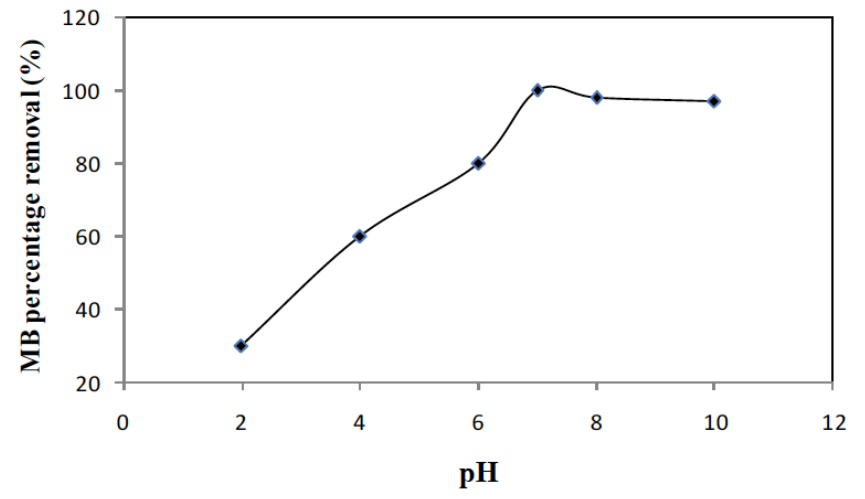

Figure 9: $\mathrm{pH}$ influence on removal percentage of $\mathrm{MB}$ using MP as bioadsorbent.

According to Wang and Li [25], the carboxyl groups on the surface of adsorbent play a major role in the adsorption of $\mathrm{MB}$. At lower $\mathrm{pH}$, protons will complete for adsorption sites with MB molecules. Moreover, a positively charged surface causes repulsion of the cationic MB molecules. Those interactions result in the lower adsorption of MB onto adsorbent. With the rise in $\mathrm{pH}$, the surface of adsorbent becomes de-protonated the competition weakens, and positively charged MB ions replace $\mathrm{H}+$ ions binding to carboxylate ions on the surface of adsorbent, resulting in increased adsorption due to electrostatic attraction. Additionally, Anwar et. al. [28], suggest that at higher $\mathrm{pH}$, the surface of the adsorbent gets more negatively charged by losing protons (deprotonation of different functional groups on the surface of the bioadsorbent) and consequently supports the uptake of positively charged (cationic) dyes due to increased electrostatic force of attraction. In this sense, and according to obtained results in this study, a possible mechanism associated with methylene blue bioadsorption by moringa pods is
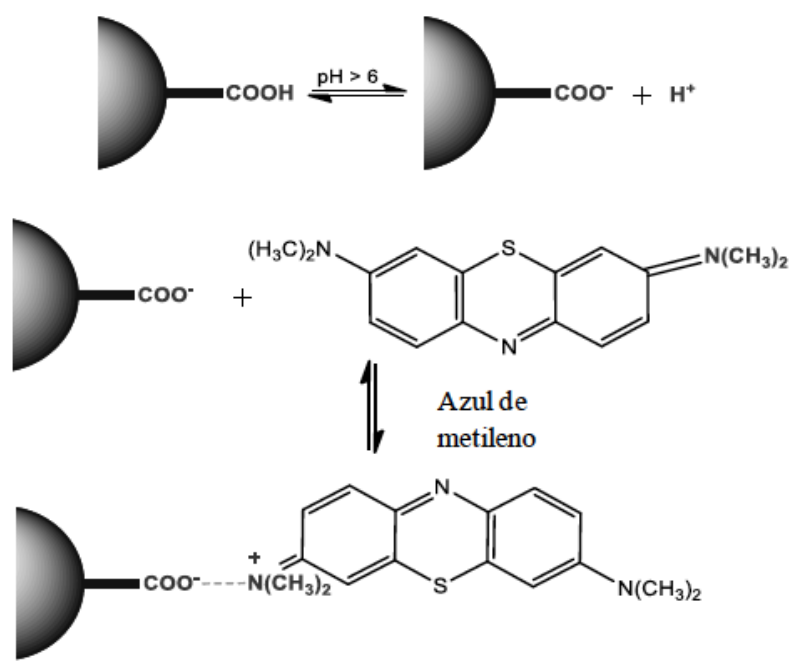

Figure 10: Possible mechanism of adsorption: moringa pods - methylene blue. proposed. Figure 10 provides a schematic representation, where a $\mathrm{pH}>6$, occurs a deprotonation of carboxylic groups present in the MP surface. Thus, the adsorption process could be favored by noncovalent interactions (intermolecular forces) attributed mainly to electrostatic attraction between the carboxilate ion negatively charged and the positively charged methylene blue molecule. Generally, these intermolecular forces are weak, but, because they are very numerous and their contribution should be important in bioadsorption process.

\section{CONCLUSION}

Moringa pods (MP) can be used as an effective alternative low-cost bioadsorbent for the removal of methylene blue (MB) from aqueous solutions under fixed-bed column operation. Adsorption process is strong influenced by solution $\mathrm{pH}$. In this case, to very low $\mathrm{pH}$ values $(\mathrm{pH}=2.0)$ is not favored adsorption process, observing the optimal percentage at about $\mathrm{pH}=7.0(\sim 100 \%)$. This bioadsorption process can be attributed mainly to electrostatic attraction between the carboxilate ions negatively charged on MP surface and the positively charged cationic MB molecules.

\section{ACKNOWLEDGEMENT}

The authors give thanks to the Ministry of Agriculture \& Land (Caracas, Venezuela), to Ramses Montaño from UNEXPO,Charallave, Venezuela, to Ecology Center (Rodrigo Díaz Lupanow), to Electron Microscopy Unit (Dra. Tamara Zoltan) and Liz Cubillan from Instrumental laboratory, Chemical Center, Venezuelan Institute of Scientific Research Venezuela.

\section{REFERENCES}

[1] Mohammed MA, Shitu, Ibrahim A. Removal of Methylene Blue Using Low Cost Adsorbent: A Review. Res J Chem Sci 2014; 4(1): 91-102.

[2] Atul Kumar K, Neha G, Chattopadhyaya MC. Removal of cationic methylene blue and malachite green dyes from aqueous solution by waste materials of Daucus carota. J Saudi Chem Soc 2014; 18: 200-207. https://doi.org/10.1016/j.jscs.2011.06.011

[3] Soni M, Sharma AK, Srivastava JK, Yadav JS. Adsorptive removal of methylene blue dye from an aqueous solution using water hyacinth root powder as a low cost adsorbent. Int J Chem Sci Appl 2012; 3(3): 338-345.

[4] Srinivas Kini M, Saidutta MB, Ramachandra Murty V. Studies on Biosorption of Methylene Blue from Aqueous Solutions by Powdered Palm Tree Flower (Borassus flabellifer). Int $\mathrm{J}$ Chem Eng 2014: 1-13. https://doi.org/10.1155/2014/306519

[5] Harminder S, Dawa T Removal of methylene blue using lemon grass ash as an adsorbent. Carbon Lett 2014; 15(2): 105-112.

https://doi.org/10.5714/CL.2014.15.2.105 
[6] Park D, Yun YS, Park J. The past, present, and future trends of biosorption. Biotechnol. Bioprocess Eng 2010; 15: 86-102. https://doi.org/10.1007/s12257-009-0199-4

[7] Conrad EK, Nnaemeka OJ, Chris AO. Adsorptive Removal of Methylene Blue from Aqueous Solution Using Agricultural Waste: Equilibrium, Kinetic and Thermodynamic Studies. Am J Chem Mater Sci 2015; 2(3): 14-25.

[8] Priyantha N, Lim LBL, Dahri MK. Dragon fruit skin as a potential biosorbent for the removal of methylene blue dye from aqueous solution. Int Food Res J 2015; 22(5): 21412148.

[9] Ikhlaq A, Azhar S, Ali Kazmi M, Ramzan N, Rustam M. Methylene Blue removal from Aqueous Solutions by using Rice Husk Ash (RHA) and Peanut Shell Ash (PSA). J Faculty Eng Technol 2014; 21(3): [online version].

[10] Muchanyereyi N, Matavire N, Gwatidzo L, Togarepi E. Removal of Methylene Blue from Aqueous Solution by Dehydrated Maize Tassels. Res J Chem Sci 2014; 4(11): 512.

[11] Song J, Zou W, Bian Y, Su F, Han R. Adsorption characteristics of methylene blue by peanut husk in batch and column modes. Desalinat 2011; 265 (1-3): 119-125. https://doi.org/10.1016/j.desal.2010.07.041

[12] Gupta VK, Suhas, Tyagi I, Agarwal S, Singh R, Chaudhary $M$, Harit A, Kushwaha S. Column operation studies for the removal of dyes and phenols using a low cost adsorbent. Global J Environ Sci Manage 2016; 2(1): 1-10.

[13] Meneghel AP, Gonçalves AC Jr, Rubio F, Cardoso DD, Lindino CA, Strey L. Biosorption of cadmium from water using moringa (moringa oleifera Lam.) seeds. Water Air Soil Pollut 2013; 224(1383): 1-13. https://doi.org/10.1007/s11270-012-1383-2

[14] Kumar RR, Abhishek K, Jyoti Kumar A, Srivastava MM, Srivastava S. Neural Network Modeling for Ni (II) Removal from aqueous system using shelled moringa oleifera seed powder as an agricultural waste. J Water Resour Prot 2010; 2: $331-338$ https://doi.org/10.4236/jwarp.2010.24038

[15] Marques T, Alves VN, Coelho LMC, Coelho NMM. Assessment of the use of moringa oleifera seeds for removal of manganese ions from aqueous systems. Bioresour.com 2013; 8 (2): 2738-275.

[16] Vikashni N, Matakite M, Kanayathu K, Subramanium S. Water purification using moringa oleifera and other locally available seeds in Fiji for heavy metal removal. Int J Appl Sci Technol 2012; 2(5): 125-129.

[17] Veeramalini JB, Sravanakumar K, Amarnath JD. Removal of reactive yellow dye from aqueous solutions by using natural coagulant (moringa oleifera). Int J Sci Environ Technol 2012; 1 (2): 56-62.
[18] Rodríguez M, Flores S, Rangel M, Argotte A. Remoción de cobre (II) en sistemas acuosos usando cápsulas de moringa oleifera: influencia del pH. Acta Microscópica 2016; 25(1): 28-38.

[19] Rodríguez M, Flores S, Rangel M, Cubillan L, Argotte A. Un estudio de la remoción de manganeso (II) a partir de sistemas acuosos usando cápsulas de moringa oleifera como bioadsorbente. Revista CENIC Ciencias Biológicas 2015; 46(especial): 424-433.

[20] Simões Mimura AM, Vieira de Almeida TV, Benedine Martelli $\mathrm{P}$, Gorgulho $\mathrm{H}$. Utilization of rice husk to remove $\mathrm{Cu}^{+2}, \mathrm{Al}^{+3}$, $\mathrm{Ni}^{+2}$ and $\mathrm{Zn}^{+2}$ from wastewater. Quím Nova 2010; 33(6): 1279-1284.

[21] Gardea-Hernández G, Ibarra-Gómez R, Flores- Gallardo SG Hernández-Escobar CA, Pérez-Romo P, Zaragoza-Contreras EA. Fast wood fiber esterification. I. Reaction with oxalic acid and cetyl alcohol. Carbohydr Polym 2008; 7: 1-8. https://doi.org/10.1016/j.carbpol.2007.05.014

[22] Simonescu CM, Ferdes M. Fungal biomass for Cu (II) uptake from aqueous system. Pol J Environ Stud 2012; 21(6): 18311839.

[23] Jeyagowri B, Yamuna RT. Biosorption of methylene blue from aqueous solutions by modified mesoporous simarouba glauca seed shell powder. Global NEST J 2015; 17(4): 701715.

[24] Yagub MT, Sen TK, Ang M. Removal of cationic dye methylene blue (MB) from aqueous solution by ground raw and base modified pine cone powder. Environ Earth Sci 2014; 71: 1507-1519. https://doi.org/10.1007/s12665-013-2555-0

[25] Wang L, Li J. Removal of methylene blue from aqueous solution by adsorption onto crofton weed stalk 2013; 8(2): 2521-2536.

[26] Alves VN, Mosquetta R, Coelho NMM, Bianchin JN, Roux KCP, Martendal E, Carasek E. Determination of cadmium in alcohol fuel using Moringa oleifera seeds as a biosorbent in an on-line system coupled to FAAS. Talanta 2010; 80(3): 1133-38.

https://doi.org/10.1016/j.talanta.2009.08.040

[27] El-Wakil AM, Abou El-Maaty WM, Ahmed Abd Al-Ridha Oudah. Methylene Blue Dye Removal from Aqueous Solution Using Several Solid Stationary Phases Prepared from Papyrus Plant. J Anal Bioanal Tech 2015; S13: 003. https://doi.org/10.4172/2155-9872.S13-003

[28] Anwar Ansari S, Khan F, Ahmad A. Cauliflower Leave, an Agricultural Waste Biomass Adsorbent, and Its Application for the Removal of MB Dye from Aqueous Solution: Equilibrium, Kinetics, and Thermodynamic Studies. Int J Anal Chem 2016: 1-10. https://doi.org/10.1155/2016/8252354 